This is an electronic reprint of the original article. This reprint may differ from the original in pagination and typographic detail.

Author(s): Ahonen, Hanna; Koskinen, H.; Valtonen, Tellervo; Taskinen, Jouni

Title: Henneguya zschokkei (Myxozoa) infection in cultured whitefish : Age-dependence, seasonality and distribution within host

Year: $\quad 2017$

Version:

Please cite the original version:

Ahonen, H., Koskinen, H., Valtonen, T., \& Taskinen, J. (2017). Henneguya zschokkei (Myxozoa) infection in cultured whitefish : Age-dependence, seasonality and distribution within host. Aquaculture, 470, 164-168.

https://doi.org/10.1016/j.aquaculture.2016.12.018

All material supplied via JYX is protected by copyright and other intellectual property rights, and duplication or sale of all or part of any of the repository collections is not permitted, except that material may be duplicated by you for your research use or educational purposes in electronic or print form. You must obtain permission for any other use. Electronic or print copies may not be offered, whether for sale or otherwise to anyone who is not an authorised user. 


\section{Accepted Manuscript}

Henneguya zschokkei (Myxozoa) infection in cultured whitefish: Age-dependence, seasonality and distribution within host

H.S. Ahonen, H. Koskinen, E.T. Valtonen, J. Taskinen

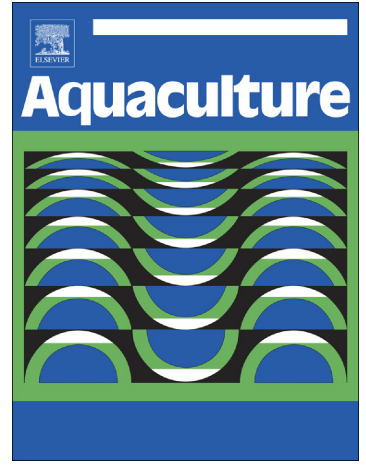

PII: S0044-8486(16)30487-2

DOI: doi: 10.1016/j. aquaculture.2016.12.018

Reference: AQUA 632457

To appear in: aquaculture

Received date: $\quad 16$ September 2016

Revised date: $\quad 14$ December 2016

Accepted date: 18 December 2016

Please cite this article as: H.S. Ahonen, H. Koskinen, E.T. Valtonen, J. Taskinen , Henneguya zschokkei (Myxozoa) infection in cultured whitefish: Age-dependence, seasonality and distribution within host. The address for the corresponding author was captured as affiliation for all authors. Please check if appropriate. Aqua(2016), doi: 10.1016/j.aquaculture.2016.12.018

This is a PDF file of an unedited manuscript that has been accepted for publication. As a service to our customers we are providing this early version of the manuscript. The manuscript will undergo copyediting, typesetting, and review of the resulting proof before it is published in its final form. Please note that during the production process errors may be discovered which could affect the content, and all legal disclaimers that apply to the journal pertain. 


\title{
Henneguya zschokkei (Myxozoa) infection in cultured whitefish: age-dependence, seasonality and distribution within host
}

\author{
H.S. Ahonen ${ }^{1}$, H. Koskinen ${ }^{2}$, E.T. Valtonen ${ }^{1} \dagger$ and J. Taskinen $^{1}$ \\ ${ }^{1}$ Department of Biological and Environmental Science, University of Jyväskylä, P.O. Box 35, FI- \\ 40014 University of Jyväskylä, Finland \\ ${ }^{2}$ Natural Resources Institute Finland, Huuhtajantie 160, 72210, Tervo, Finland \\ $\dagger$ Deceased 23 July, 2016
}

Corresponding author

E-mail address: hanna.ahonen@jyu.fi (H.S. Ahonen).

Key words: European whitefish, Coregonus lavaretus, Myxosporea, Henneguya zschokkei

\begin{abstract}
Whitefish (Coregonus lavaretus) is an important species for European fisheries and aquaculture. Recently, the myxosporean Henneguya zschokkei has been observed to infect the muscles of whitefish in fish farms. Plasmodia of $H$. zschokkei prevent marketing of the fillet and cause economic losses. The factors associated with occurrence of the parasite in fish farms have not been investigated previously. We studied age-dependence, seasonality, and within-host distribution of $H$. zschokkei plasmodia in farmed whitefish by examining a total of 1,599 fish. Distribution of plasmodia within the fish was not uniform. When the fillet was divided into parts, the number of plasmodia was positively correlated with the mass of the part, suggesting that larger muscles of whitefish may be particularly susceptible to, or preferred by H. zschokkei. Plasmodia were rarely found in $1 \mathrm{y}$ old whitefish (prevalence $0.2 \%$ ). The youngest age group substantially infected was 2 y old fish with the prevalence of $13.1 \%$, which did not differ statistically from $3 \mathrm{y}$ old fish with $17.1 \%$ infected. Mean intensity of infection in these three age groups was 1.0, 11.0 and 8.1 plasmodia per fish, respectively. The infections started to appear in August both in 1 and 2 y old fish, which suggests a seasonal hatching of parasite actinospores (the infective stage released from the definitive host). Condition of fish was not related to the number of plasmodia.
\end{abstract}

Statement of relevance: This is the first study of H. zschokkei in whitefish (C. lavaretus) in fish farm. There is a need for increased knowledge of $H$. zschokkei infection in cultured whitefish, as this species is being largely used in aquaculture and for stocking purposes.

\section{Introduction}

Parasitic diseases represent a severe threat to fisheries and aquaculture production around the world, causing significant economic losses through reduced growth, morbidity and mortality of fish (e.g., Williams and Jones, 1994; Woo, 1995; Lom and Dyková, 2006; Lafferty et al., 2015). Whitefish (Coregonus lavaretus) is an economically important fish species with a wide range of occurrence in the northern hemisphere. For example, whitefish is one of the most popular fish species in professional, sport and commercial fishery in Finland, with a total catch of 1.8 x $10^{6} \mathrm{~kg}$ in 2014 (Natural Resources Institute Finland), and a total fish farm production of $1.2 \times 10^{6} \mathrm{~kg}$ per year for food (Savolainen, 2014). Henneguya zschokkei (Myxosporea) infects coregonids, including whitefish, in Europe and Russia (Lom and Dyková, 1992). H. zschokkei infection was recognized in Finland already in the early 1900s (Luther, 1909). Thereafter, it has been documented in a number of Finnish lakes (e.g., Valtonen et al., 1988; Hyvärinen et al., 2000; Leinonen and Mutenia, 2009). 
In recent years, this myxosporean has also been found in fish farms with plasmodia up to 20-30 mm in size found in the muscles of whitefish. The presence of such plasmodia makes fish unattractive and thereby hamper whitefish fishery and aquaculture.

Some authors have suggested that $H$. zschokkei and Henneguya salminicola are synonyms for the same species (e.g., Boyce et al., 1985; Lom and Dyková, 1992). H. salminicola is commonly known to infect salmonids in the North America and Asian coastal waters (Boyce et al., 1985). Although parasitized fish can be found from the sea, Boyce et al. (1985) suggest that Henneguya infections take place in the freshwater habitats.

Class Myxosporea belongs to the Phylum Cnidaria (Chang et al., 2015) and harbor endoparasites with a life cycle involving an invertebrate and a vertebrate host. Typically, the definitive host of Myxosporea is an oligochaete and the intermediate host is a fish. The oligochaete host of $H$. zschokkei is not known. Majority of myxosporean infections are harmless to fish, although serious diseases are known (e.g., Lom and Dyková, 1992; Kent et al., 2001). Myxosporeans clearly have substantial economic impacts on fisheries and aquaculture (e.g., Diamant, 1992) particularly because there are no effective treatments or vaccines available (e.g., Gómez et al., 2014).

Here, we address several basic questions that are essential in preventing or mitigating the harm of $H$. zschokkei on whitefish aquaculture and fisheries. (i) What is the distribution of infection within an individual whitefish? It is known that $H$. zschokkei plasmodia occupy muscles of host fish (Eiras, 2002), but the spatial distribution pattern of plasmodia within the musculature has not been studied. When processing the fish fillet it will be useful to know where the plasmodia occur within the muscles, in order to, perhaps, develop measures cutting out the plasmodia from the muscles. (ii) Are there certain seasons when infection is more intense, perhaps due to the life cycle of the parasite, or seasonal behaviors of the intermediate host? (iii) Does the parasite infect certain age classes of whitefish? In addition, it would be important to know the development rate of the parasite, i.e., at what age the plasmodia become visible in fish. Finally, (iv) it is also unclear whether the infection affects the condition of the fish. For these reasons, the aims of the present study were to investigate the development rate, age-dependency of infection, seasonality of occurrence and the spatial distribution of plasmodia within the muscles, as well as differences in condition factor between $H$. zschokkei -infected and uninfected whitefish in a (freshwater) fish farm.

\section{Material and methods}

\subsection{Whitefish material}

Whitefish specimens were obtained from the Tervo fish farm (Natural Resources Institute Finland). Three age groups were investigated: 1 y old (year class 2008), 2 y old (year class 2007) and 3 y old (year class 2005) fish (Table 1). Age group 1 y old fish also included whitefish which were moved for purpose of another experiment, at the age of 0 y old fish (after first summer) from the fish farm to Konnevesi Research Station (University of Jyväskylä) and studied at the age of $1 \mathrm{y}$ old fish. Whitefish used in the present study were grown in fiber glass tanks kept indoor, and were fed with dry pellets. Water supply to the fish farm was from Lake Nilakka (surface area $168 \mathrm{~km}^{2}$, average depth $4.9 \mathrm{~m}$ ) and to the research station from Lake Konnevesi (surface area $200 \mathrm{~km}^{2}$, average depth $12.5 \mathrm{~m}$ ). H. zschokkei has been found in wild whitefish population in both lakes. The fish farm and research station are located in the watershed of the River Kymijoki, flowing to the Gulf of Finland in the Baltic Sea. The distance between the fish farm and the research station is 50 $\mathrm{km}$.

\subsection{Examination of fish}


In 2008, 3 y old whitefish $(n=164)$ were examined fresh in June, July and August from the fish farm (Table 2). In 2009, approximately 502 y old fish whitefish were collected every second week from May to September from the fish farm $(n=381)$, and stored in $-20{ }^{\circ} \mathrm{C}$ for a later examination. Similarly, in 2009, approximately 501 y old fish whitefish from the fish farm $(\mathrm{n}=481)$ and the research station $(n=573)$ were collected every second week from May to October and stored in -20 ${ }^{\circ} \mathrm{C}$ to be examined later (Table 3 ).

The mass and length of each fish was measured. In 2008, 3 y old fish were filleted into $5 \mathrm{~mm}$ slices and $H$. zschokkei plasmodia were observed visually on a glass table using transmitted light. In 2009 ( 1 and 2 y old fish) $H$. zschokkei plasmodia were examined by pressing muscle tissue samples between two glass plates $(8.0 \times 20.0 \mathrm{~cm}$ in size) and using a dissection microscope with $6.3-25 \mathrm{x}$ magnification (Olympus SZX9). Occurrence of $H$. zschokkei myxospores within plasmodia was microscopically verified using $400 \mathrm{x}$ magnification (Motic B series).

In the case of $2 \mathrm{y}$ old fish from the fish farm in 2009, position of each plasmodium was recorded. Each fillet was divided dorso-ventrally and anterior-posteriorly into six parts, totaling 12 parts per one fillet (Fig. 1). Total number of $H$. zschokkei plasmodia per part was quantified by combining numbers of plasmodia from both sides of the fish. To be able to estimate the mass of muscles in each of the 12 parts, a separate sample of whitefish $(n=11)$ with same age and size as in 2009 was collected, muscles divided in 12 parts as in 2009, and weighed to the nearest mg.

\subsection{Statistics}

Pearson Chi-Square Test was used to analyse differences in prevalence of infection between age groups, prevalence being defined as the proportion of infected fish among all fish in the sample. Differences between locations within fillet (both sides of fish combined) in the mean number of plasmodia were estimated with nonparametric Wilcoxon Signed Ranks test. We used One-way ANOVA to analyse the intensity of infection of $H$. zschokkei plasmodia in whitefish among age groups, mean intensity being defined as the mean number of plasmodia per infected fish. Condition index of fish was calculated using the formula $\mathrm{K}=100 \mathrm{x}\left(\right.$ weight/length ${ }^{3}$ ) and compared between infected and uninfected fish with independent samples t-test. All statistical analyses were performed with SPSS Version 22.0. To account for multiple tests, the Bonferroni correction was applied to pvalues so that 0.05 was divided by the number of tests to achieve critical p-value $\alpha$.

\section{Results}

In the fish farm, none of the $1 \mathrm{y}$ old fish were infected, and in the research station the prevalence of infection among $1 \mathrm{y}$ old fish was $0.4 \%$ (Table 1). Difference between the fish farm and research station among the $1 \mathrm{y}$ old fish in the prevalence of infection was not significant $\left(\chi^{2}=0.344\right.$, $\mathrm{df}=1$, $P=0.588$ ). Prevalence of infection in 2 and 3 y old fish was 13.1 and $17.1 \%$, respectively (Table 1 ), being statistically significantly higher than among the $1 \mathrm{y}$ old fish (all studied $1 \mathrm{y}$ old fish combined) $\left(\chi^{2}=134.0, \mathrm{df}=1, P<0.001\right.$ and $\chi^{2}=168.4$, df $=1, P<0.001$, respectively). However, prevalence of $H$. zschokkei infection did not differ significantly between 2 and 3 y old whitefish $\left(\chi^{2}\right.$ $=1.459$, df $=1, P=0.227$ ). The two fish from age group $1 \mathrm{y}$ old fish were infected only with a single $H$. zschokkei plasmodium whereas in 2 and 3 y old fish individuals the maximum number of plasmodia per fish was 101 and 32 respectively. However, heavily infected fish were rare; most of the infected fish had only 1-20 plasmodia, showing an aggregated distribution. Mean ( \pm s.e.) intensity (and median) of H. zschokkei infection in the age group 1,2 and 3 y old fish was $1.0 \pm 0$, $11.0 \pm 2.5$ (median 3.0) and 8.1 \pm 1.6 (median 5.5) (Table 1), respectively. The difference was not significant between 1, 2 and 3 y old fish (One-way ANOVA; $\mathrm{df}=2, \mathrm{~F}=0.711, \mathrm{P}=0.494$ ).

The infection was notable for the first time in August from 1 and $2 \mathrm{y}$ old fish. The first infected individual was found in the $1 \mathrm{y}$ old whitefish in August and the second one in October from the 
research station. In $2 \mathrm{y}$ old fish, the prevalence of infection was zero from the beginning of June to 13th of July. When the first H. zschokkei observation was made in early August almost one third of the fish were infected (Table 3 ). There was a statistically significant increase in the prevalence of infection among 2 y old fish from $13^{\text {th }}$ of July to $3^{\text {rd }}$ of August (Table 3 , Pearson $\chi^{2}=19.392$, df $=1$, $P=0.001$ ). From early August on, the parasite was present in 22.0-36.7 \% of fish with mean intensities varying from 7.9 to 18.9 plasmodia per fish to the end of the study period in September (Table 3). There was no statistically significant difference between sampling dates from $3^{\text {rd }}$ of August to $7^{\text {th }}$ of September in the prevalence of infection (Pearson $\chi^{2}=2.814, \mathrm{df}=3, P=0.421$ ) or in the intensity of infection (One-way ANOVA, $\mathrm{df}=3, \mathrm{~F}=1.100, \mathrm{P}=0.359$ ) among the 2 y old fish.

Among the $3 \mathrm{y}$ old whitefish, plasmodia of $H$. zschokkei were already evident in the first samples collected in June, and were present throughout the study period till August. The monthly prevalence of infection varied from 6.9 to $26.5 \%$ (Table 2). Prevalence of infection in July was significantly lower than in June or August $\left(\chi^{2}=6.315\right.$, $\mathrm{df}=1, P=0.012$ and $\chi^{2}=8.833$, $\mathrm{df}=1, P=0.003$, respectively). The mean monthly intensities of infection, varying from 6.4 to 14.4 (Table 2), did not differ from each other among the 3 y old whitefish (One-way ANOVA; df $=2, \mathrm{~F}=1.914, \mathrm{P}=$ 0.169).

Mean ( \pm s.e.) intensity of infection was higher on the dorsal side of the whitefish, $6.2 \pm 1.3$, compared to the ventral side, $4.8 \pm 1.3(\mathrm{n}=50)$ (Wilcoxon Signed Ranks Test, $\mathrm{Z}=-2.444, P=$ 0.015). Mass-related intensity, i.e. the mean ( \pm s.e.) intensity of infection per mass ( $\mathrm{g}$ ) of muscle part (plasmodium number/mean weight of the part) did not differ between dorsal $(0.10 \pm 0.02)$ and ventral $(0.10 \pm 0.03)$ side (Wilcoxon Signed Ranks Test, $\mathrm{Z}=-0.391, \mathrm{P}=0.696)$. Highest numbers of plasmodia were observed in the middle section of the fish (areas D2-D5 and V2-V5; Fig. 2). Statistically significant differences between parts within the fish fillet were mainly characterized with the most anterior and most posterior sites having lower number of plasmodia than the middle parts (Table 4 and Table 5). There was a statistically significant positive correlation between the mass of the muscle and number of plasmodia in the muscles (from dorsal: Pearson Correlation = 0.856, $P=0.030, \mathrm{~N}=6$ and from ventral Pearson Correlation $=0.951, P=0.004, \mathrm{~N}=6$ ) (Fig. 3).

Finally, there were no differences in the condition factor between infected and uninfected fish, as analysed for the $2 \mathrm{y}$ old fish from August to September (Independent Samples t-test, $\mathrm{t}=0.004, \mathrm{df}=$ $178, \mathrm{P}=0.997$ ) and from $3 \mathrm{y}$ old fish from June to August (Independent Samples t-test, $\mathrm{t}=0.000$, df $=161, \mathrm{P}=1.000)$.

\section{Discussion}

Studies on Myxozoa diseases have shown a connection between water temperature (seasonality) and outbreak of the diseases. The diseases usually tend to occur when the water temperature is high, $\sim 15-20{ }^{\circ} \mathrm{C}$. This is perhaps not surprising because temperature is known to affect both the parasite occurrence in fish and the release of spores from invertebrate hosts (e.g., El-Matbouli et al., 1999; Tops et al., 2006). In our study, water temperatures started to increase in April and the highest temperatures were observed in July and August. We found a clear seasonal pattern in the infection dynamics. In the 1 and $2 \mathrm{y}$ old fish, new infections appeared in August. This indicates a distinct seasonal rhythm in the release of $H$. zschokkei actinospores from the definitive hosts, oligochaetes. These results are in accordance with previous studies on temperature dependence of Myxozoa species in fish hosts that have suggested a seasonal release of actinospores in Myxobolus cerebralis (El-Matbouli et al., 1999), Ceratonova shasta (Hallett et al., 2012), Tetracapsuloides bryosalmonae (Tops et al., 2006) and Henneguya ictaluri (Wise et al., 2004). Alternatively, if the actinospores release and infection of fish are not temporally limited on seasonal basis, the current result suggests that at least the development of plasmodia in fish follows a clear seasonal pattern - with a burst of microscopically visible, new infections in August. Haaparanta et al. (1994) showed a clear 
seasonality in the life cycle and infestation of host fish by Henneguya creplini in Finland. New infections appeared on the gills of Perca fluviatilis in July, and mature plasmodia with fully developed myxospores were found mainly in April-May. After that the old plasmodia disappeared from the gills so that in June the fish mostly had no $H$. creplini infections. This suggests that the life cycles of $H$. zschokkei and $H$. creplini, with respect to seasonal infection of fish, may follow a similar pattern. The difference with these parasites, however, is that the plasmodia of $H$. creplini in gills rupture, release myxospores and disappear every summer while H. zschokkei stay in the host musculature probably until the host dies.

Henneguya species can increase mortality of fish and hamper fish farming, but most of them are quite harmless (Lom and Dyková, 2006). In our study we did not find any evidence that the parasite has negative effect on the condition of the host as measured by a coefficient index based on the size of the fish. Moreover, we did not observe any fish mortality during our study. Nevertheless, it should be noted that if the plasmodia do not stop growing, it is possible that the harmful effects of H. zschokkei is amplified in older fish, and requires further study.

What can we deduce from these results about the exposure of fish to $H$. zschokkei actinospores and the development of plasmodia? Although the present results showed that the $1 \mathrm{y}$ old whitefish could be infected by $H$. zschokkei (extremely rarely; 2 cases out of 1054 fish, $0.2 \%$ ), in practice the youngest age group infected was 2 y old fish. Judging from the seasonally synchronized appearance of infections in fish in August, the exposure of fish to $H$. zschokkei actinospores is probably also seasonal. However, the precise time of this event remains unknown.

Similarly, we acknowledge that the age of fish at the time of exposure to the parasite is unknown. Moran et al. (1998) found that myxospores of Kudoa sp. are apparent in the host six months after infection. Szèkely et al. (2001) infected parasite-free roach fingerlings with actinospores of Myxobolus pseudodispar and young plasmodia were observed 80 days after infection. However, in our study all fish were kept in equal conditions, in indoor tanks up to the age of $2 \mathrm{y}$ old fish and, thus, up to the outbreak of the infection. Therefore, it is reasonable to assume that all of the present fish have been exposed to H. zschokkei actinospores throughout their lives. If the exposure has started already at the age of $0 \mathrm{y}$ old fish, but the plasmodia are found (predominantly) not until $2 \mathrm{y}$ old fish of age, it is likely that the development of H. zschokkei inside the fish may be very slow. If the parasite development within fish tissue would be quick (weeks) we should have probably found a high prevalence of infection in $1 \mathrm{y}$ old whitefish.

The parasite plasmodia in whitefish muscles were aggregated. Most of the infected fish had only 1-20 plasmodia. Distribution of the number of plasmodia resembled the negative binomial distribution which is common in most parasite populations in their host (Shaw and Dobson, 1995). It might suggest differences in susceptibility among individuals if one assumes equal exposure in the tanks. Most of the plasmodia located in the middle of fillet where the mass of the muscle were highest. Correlation was positive between muscle mass and amount of the plasmodia in the site. Studies on the prevalence of Kudoa sciaenae had shown that the prevalence and intensity was highest behind the head and in the anterior part of fish, which was also the highest mean dry weight of the muscle (Oliva et al., 1992). However, plasmodia of H. zschokkei were not accumulated in any single part of the fillet, so cutting the fish in a particular way to separate plasmodia may not be possible. On the other hand it is possible to remove plasmodia from fresh fillet, if infection intensity is low.

Controlling Myxozoa diseases is difficult because there are no treatments or vaccines available (Yokoyama et al., 2012). Thus, preventive measures to avoid infections are very important. These include e.g., reduction of stress (Sitjá-Bobadilla et al., 2015), improving water quality by filtering incoming water or using clean water supplies from parasite-free water bodies (e.g. Enteromyxum leei, Yokoyama and Shirakashi, 2007), exposure to ozone (e.g., Ceratomyxa shasta, Tipping, 1988) or UV (e.g., M. cerebralis; Hedrick et al., 2000; Hedrick et al., 2012). Our study provides the first insight into the seasonality and development of the myxosporean parasite H. zschokkei infecting 
commercially important whitefish stocks. To mitigate the harmful effects of the parasite on whitefish aquaculture and fisheries, more research on the life cycle, including identification of the definitive oligochaete host of $H$. zschokkei, is needed.

\section{Acknowledgements}

We would like to thank staff of Tervo fish farm and staff and trainees of Konnevesi Research Station and Department of Biological and Environmental Science, University of Jyväskylä for help and assistance during the study. We are also grateful to the "parasite group" of JYU, Punidan Jeyasingh and two anonymous referees for valuable comments on the manuscript, and P. Jeyasingh for improving the language. The study was supported by the EU Fisheries Fund (grant: 1000087 to JT), the Finnish Women's Science Foundation, Olvi Foundation, Finnish Cultural Foundation (Central Finland regional Fund), the Finnish Food and Drink Industries Federation (ETL) and Societas pro Fauna et Flora Fennica.

\section{References}

Boyce, N.P., Kabata, Z., Margolis, L., 1985. Investigations of the distribution, detection, and biology of Henneguya salminicola (Protozoa, Myxozoa), a parasite of the flesh of Pacific Salmon. Can. Tech. Rep. Fish. Aquat. Sci., 1405, 55 p.

Chang, E.S., Neuhof, M., Rubinstein, N.D., Diamant, A., Philippe, H., Huchon, D., Cartwright, P., 2015. Genomic insights into the evolutionary origin of Myxozoa within Cnidaria. Proc Natl Acad Sci U S A. 112 (48), 14912-14917.

Diamant, A., 1992. A new pathogenic histozoic Myxidium (Myxosporea) in cultured gilt-head sea bream Sparus aurata L. Bull. Eur. Ass. Fish. Pathol. 12, 64-66.

Eiras, J.C., 2002. Synopsis of the species of the genus Henneguya Thélohan, 1892 (Myxozoa: Myxosporea: Myxobolidae). Syst. Parasitol. 52, 43-54.

El-Matbouli, M., McDowell, T.S., Antonio, D.B., Hedrick, R.P., 1999. Effect of water temperature on the development, release and survival of the triactinomyxon stage of Myxobolus cerebralis in its oligochaete host. Int. J. Parasitol. 29, 627-641.

Gómez, D., Bartholomew, J., Sunyer, J.O., 2014. Biology and Mucosal Immunity to Myxozoans. Dev Comp Immunol. 43(2), 243-256.

Haaparanta, A., Valtonen, E.T., Hoffmann, R., 1994. Pathogenicity and seasonal occurrence of Henneguya creplini (Protozoa, Myxosporea) on the gills of perch Perca fluviatilis in central Finland. Dis. Aquat. Org. 20, 15-22.

Hallett, S.L., Bartholomew, J.L., 2012. Myxobolus cerebralis and Ceratomyxa Shasta. In: Woo P.T.K., Buchmann, K. (Eds.), Fish parasites: pathobiology and protection. CABI, Oxfordshire, pp. 131-162.

Kent, M.L., Andree, K.B., Bartholomew, J.L., El-Matbouli, M., Desser, S.S., Devlin, R.H., Feist, S.W., Hedrick, R.P., Hoffmann, R.W., Khattra, J., Hallett, S.L., Lester, R.J.G., Longshaw, M., Palenzeula, O., Siddall, M.E., Xiao, C., 2001. Recent advances in our knowledge of the Myxozoa. J. Eukaryot. Microbiol. 48, 395-413. 
Hedrick, R.P., McDowell, T.S., Marty, G.D., Mukkatira, K., Antonio, D.B., Andree, K.B., Bukhari, Z., Clancy, T., 2000. Ultraviolet irradiation inactivates the waterborne infective stages of Myxobolus cerebralis: a treatment for hatchery water supplies. Dis. Aquat. Org. 42, 53-59.

Hedrick, R.P., McDowell, T.S., Adkison, M.A., Myklebust, K.A., Mardones, F.O., Petri, B., 2012. Invasion and initial replication of ultraviolet irradiated waterborne infective stages of Myxobolus cerebralis results in immunity to whirling disease in rainbow trout. Int. J. Parasitol. 42, 657-666.

Hyvärinen, P., Sutela, T. Korhonen, P., 2000. Combining fishery prohibition with stocking of landlocked salmon, Salmo salar L.: an effort to gain bigger yield and individual size. Fisheries Manag. Ecol. 7, 503-514.

Lafferty, K.D., Harvell, C.D., Conrad, J.M., Friedman, C.S., Kent, M.L., Kuris, A.M., Powell, E.N., Rondeau, D., Saksida S.M., 2015. Infectious Diseases Affect Marine Fisheries and Aquaculture Economics. Annu. Rev. Mar. Sci. 7, 471-96.

Leinonen, K., Mutenia, A., 2009. Lokan ja Porttipahdan tekojärvien kalakantojen tila. Metsähallituksen luonnonsuojelujulkaisuja. Sarja A 184. 2009. (in Finnish)

Lom, J., Dyková, I., 1992. Protozoan parasites of fishes. Elsevier. Amsterdam - London - New York - Tokyo.

Lom, J., Dyková, I., 2006. Myxozoan genera: definition and notes on taxonomy, life-cycle terminology and pathogenic species. Folia Parasitol. 53(1), 1-36.

Luther, A., 1909. Uber Triaenophorus robustus Olsson und Henneguya zschokkei Gurley als Parasiten von Coregonus albula aus dem See Sapsojärvi. Meddel. Soc. Pro Fauna et Fl. Fenn. 35, 58-59.

Moran, J.D.W., Kent, M.L., Khattra, J., Webster, J.M., 1998. Endogenous development of the myxosporean parasite associated with post-mortem myoliquefaction. Abstracts of the 39th Annual Western Fish Disease Workshop, American Fisheries Society, 24-26 June 1998, Parksville, British Columbia, p. 24.

Natural Resources Institute Finland. Statistics database: Fishery catch in Finland 2014. http://statdb.luke.fi/PXWeb/pxweb/en/LUKE/LUKE_06\%20Kala\%20ja\%20riista_02\%20Rakenn e\%20ja\%20tuotanto_08\%20Kalastus\%20yhteensa/?tablelist=true\&rxid=05700cbe-0947-43998645-5e55de070e36 (accessed 13.9.2016)

Oliva, M., Luque, J.L., Teran, L., Llican, L., 1992. Kudoa sciaenae (Myxozoa: Multivalvulidae) cysts distribution in the somatic muscles of Stellifer minor (Tschudi, 1844) (Pisces: Sciaenidae). Mem. Inst. Oswaldo Cruz vol.87 no.1 Rio de Janeiro Jan./Mar. 1992.

Savolainen, R., 2014. Aquaculture 2013. Finnish Game and Fisheries Research Institute. Tilastoja, nro 5, 2014.

Shaw, D.J., Dobson, A.P., 1995. Patterns of macroparasite abundance and aggregation in wildlife populations: A quantitative review. Parasitology 111, S111-27. 
Sitjá-Bobadilla, A., Schmidt-Posthaus, H., Wahli, T., Holland, J.W., Secombes, C.J., 2015. Fish Immune Responses to Myxozoa, in: Okamura, B., Gruhl, A., Bartholomew, J.L. (Eds.), Myxozoan Evolution, Ecology and Development. Springer International Publishing Switzerland 2015. pp. 253280.

Szèkely, C.S., Molnàr, K.. Ràcz, O., 2001. Complete developmental cycle of Myxobolus pseudodispar (Gorbunova) (Myxosporea: Myxobolidae). J. Fish Dis. 24, 461-468.

Tipping, J.M., 1988. Ozone control of ceratomyxosis: survival and growth benefits to steelhead and cutthroat trout. Prog. Fish. Cult., Vol. 50, No. 4, 202-210.

Tops, S., Lockwood, W., Okamura, B., 2006. Temperature-driven proliferation of Tetracapsuloides bryosalmonae in bryozoan hosts portends salmonid declines. Dis. Aqua. Org. 70, 227-236.

Valtonen, E.T., Brummer-Korvenkontio, H., Rahkonen, R., 1988. A Survey of the parasites of coregonus from three water bodies in Finland. Finnish Fisheries Research 9, 313-322.

Williams, H.H., Jones, A., 1994. Parasitic worms of fish. Taylor and Francis, London, 593 pp.

Wise, D.J., Camus, A.C., Schwedler, T., Terhune, J., 2004. Health management. In: Tucker CS, Hargreaves JA (Eds), Biology and culture of the channel catfish. 34, 1 edn. Elsevier, Amsterdam, pp 444-502.

Woo, P.T.K., 1995. Fish diseases and disorders. vol. I. Protozoan and metazoan infections. CAB International, Oxon, UK, 808 pp.

Yokoyama, H., Grabner, D., Shirakashi,. S., 2012. Transmission biology of the Myxozoa. In: Carvalho ED (Eds.), Healt and environment in aquaculture. InTech, Online, pp 3-42.

Yokoyama, H., Shirakashi, S., 2007. Evaluation of hyposalinity treatment on infection with Enteromyxum leei (Myxozoa) using anemonefish Amphiprion spp. as experimental host. Bull Eur Assoc Fish Pathol 27, 74-78. 


\section{Tables}

Table 1. Sampling year, numbers of whitefish studied (n), fish age, mean length $(\mathrm{mm})$ and mass (g) of fish, with prevalence and mean \pm s.e. and median intensities of infection of $H$. zschokkei infection in the fish farm (FF) and research station (RS). Different superscript letter denotes statistically significant difference between groups.

\begin{tabular}{cccccccc}
\hline & $\begin{array}{c}\text { Sampling } \\
\text { year }\end{array}$ & $\mathrm{n}$ & Age & Length/Mass & Prev. (\%) & Intensity & Median \\
\hline FF & 2008 & 164 & 3 & $259 / 155$ & $17.1^{\mathrm{b}}$ & $8.1 \pm 1.6$ & 5.5 \\
FF & 2009 & 381 & 2 & $244 / 153$ & $13.1^{\mathrm{b}}$ & $11.0 \pm 2.5$ & 3 \\
FF & 2009 & 481 & 1 & $159 / 036$ & $0.0^{\mathrm{a}}$ & - & - \\
RS & 2009 & 573 & 1 & $180 / 047$ & $0.4^{\mathrm{a}}$ & $1.0 \pm 0$ & 1 \\
\hline
\end{tabular}

Table 2. Three years old whitefish (year class 2005) from the fish farm studied in 2008. Months of collection (2-4 samples per month combined), numbers of fish studied (n), mean length (mm) and mass $(\mathrm{g})$ of fish, with prevalence and mean \pm s.e. and median intensities of infection and range of plasmodium numbers per fish.

\begin{tabular}{rcccccc}
\hline Month & $\mathrm{n}$ & Length/Mass & Prevalence & Intensity & Median & Range \\
\hline June & 43 & $272 / 185$ & $23.3 \%$ & $6.4 \pm 2.2$ & 3.5 & $0-24$ \\
July & 72 & $249 / 128$ & $6.9 \%$ & $14.4 \pm 5.3$ & 16.0 & $0-32$ \\
August & 49 & $262 / 169$ & $26.5 \%$ & $7.0 \pm 1.9$ & 5.0 & $0-28$ \\
\hline
\end{tabular}

Table 3. Two years old whitefish (year class 2007) from the fish farm studied in 2009. Dates of collection, numbers of fish studied (n), mean length ( $\mathrm{mm}$ ) and mass $(\mathrm{g})$ of fish, with prevalence, mean \pm s.e. and median intensities of infection and range of plasmodia numbers per a fish at farm.

\begin{tabular}{rcccccc}
\hline Date & $\mathrm{n}$ & Length/Mass & Prevalence & Intensity & Median & Range \\
\hline 02.06. & 50 & $227 / 110$ & 0 & 0 & 0 & 0 \\
11.06. & 50 & $243 / 126$ & 0 & 0 & 0 & 0 \\
29.06. & 50 & $228 / 129$ & 0 & 0 & 0 & 0 \\
13.07. & 51 & $238 / 146$ & 0 & 0 & 0 & 0 \\
03.08. & 49 & $243 / 137$ & $30.6 \%$ & $7.9 \pm 2.4$ & 3.5 & $1-39$ \\
13.08. & 50 & $252 / 166$ & $22.0 \%$ & $8.7 \pm 3.1$ & 4 & $1-34$ \\
24.08. & 50 & $258 / 190$ & $24.0 \%$ & $18.9 \pm 8.5$ & 5 & $1-101$ \\
07.09. & 30 & $284 / 262$ & $36.7 \%$ & $9.3 \pm 3.9$ & 3 & $1-41$ \\
\hline
\end{tabular}


Table 4. Paired comparisons (Wilcoxon Signed Ranks Test) of mean numbers of plasmodia of $H$. zschokkei in the dorsal part of fillet of $2 \mathrm{y}$ old whitefish from the fish farm. Six sites from anterior to posterior end are marked from D1 to D6 (Fig. 1). To account for multiple comparisons, critical $P$ value was set to $0.0033(0.05 / 15)$. Statistically significant differences are given in bold.

\begin{tabular}{rrrrrrr}
\hline & D1 & D2 & D3 & D4 & D5 & D6 \\
\hline D1 & $*$ & $<\mathbf{0 . 0 0 1}$ & $<\mathbf{0 . 0 0 1}$ & $<\mathbf{0 . 0 0 1}$ & $\mathbf{0 . 0 0 1}$ & 0.436 \\
D2 & $<\mathbf{0 . 0 0 1}$ & $*$ & 0.505 & 0.194 & 0.257 & $<\mathbf{0 . 0 0 1}$ \\
D3 & $<\mathbf{0 . 0 0 1}$ & 0.505 & $*$ & 0.560 & 0.088 & $<\mathbf{0 . 0 0 1}$ \\
D4 & $<\mathbf{0 . 0 0 1}$ & 0.194 & 0.560 & $*$ & 0.017 & $<\mathbf{0 . 0 0 1}$ \\
D5 & $\mathbf{0 . 0 0 1}$ & 0.257 & 0.088 & 0.017 & $*$ & $<\mathbf{0 . 0 0 1}$ \\
D6 & 0.436 & $<\mathbf{0 . 0 0 1}$ & $<\mathbf{0 . 0 0 1}$ & $<\mathbf{0 . 0 0 1}$ & $<\mathbf{0 . 0 0 1}$ & $*$ \\
\hline
\end{tabular}

Table 5. Paired comparisons (Wilcoxon Signed Ranks Test) of mean numbers of plasmodia of $H$. zschokkei in the ventral part of fillet of $2 \mathrm{y}$ old whitefish from the fish farm. Six sites from anterior to posterior end are marked from D1 to D6 (Fig. 1). To account for multiple comparisons, critical $P$ value was set to 0.0033 (0.05 / 15). Statistically significant differences are given in bold.

\begin{tabular}{rrrrrrrr}
\hline & V1 & V2 & V3 & V4 & V5 & V6 \\
\hline V1 & $*$ & $\mathbf{0 . 0 0 1}$ & $<\mathbf{0 . 0 0 1}$ & $<\mathbf{0 . 0 0 1}$ & 0.050 & 0.096 \\
V2 & $\mathbf{0 . 0 0 1}$ & $*$ & 0.038 & 0.014 & 0.159 & $\mathbf{0 . 0 0 1}$ \\
V3 & $<\mathbf{0 . 0 0 1}$ & 0.038 & $*$ & 0.060 & 0.009 & $<\mathbf{0 . 0 0 1}$ \\
V4 & $<\mathbf{0 . 0 0 1}$ & 0.014 & 0.060 & $*$ & $<\mathbf{0 . 0 0 1}$ & $<\mathbf{0 . 0 0 1}$ \\
V5 & 0.050 & 0.159 & 0.009 & $<\mathbf{0 . 0 0 1}$ & $*$ & $\mathbf{0 . 0 0 3}$ \\
V6 & 0.096 & $\mathbf{0 . 0 0 1}$ & $<\mathbf{0 . 0 0 1}$ & $<\mathbf{0 . 0 0 1}$ & $\mathbf{0 . 0 0 3}$ & $*$ \\
\hline
\end{tabular}


Figures

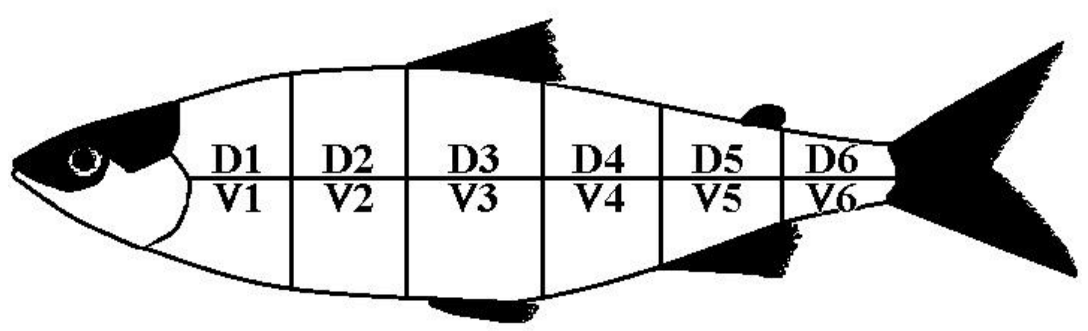

Fig. 1. "Fish map" used to record locations of H. zschokkei plasmodia within the 2 y old fish. Dorsal (D) and ventral (V) side of the fish was divided into six separate sites.

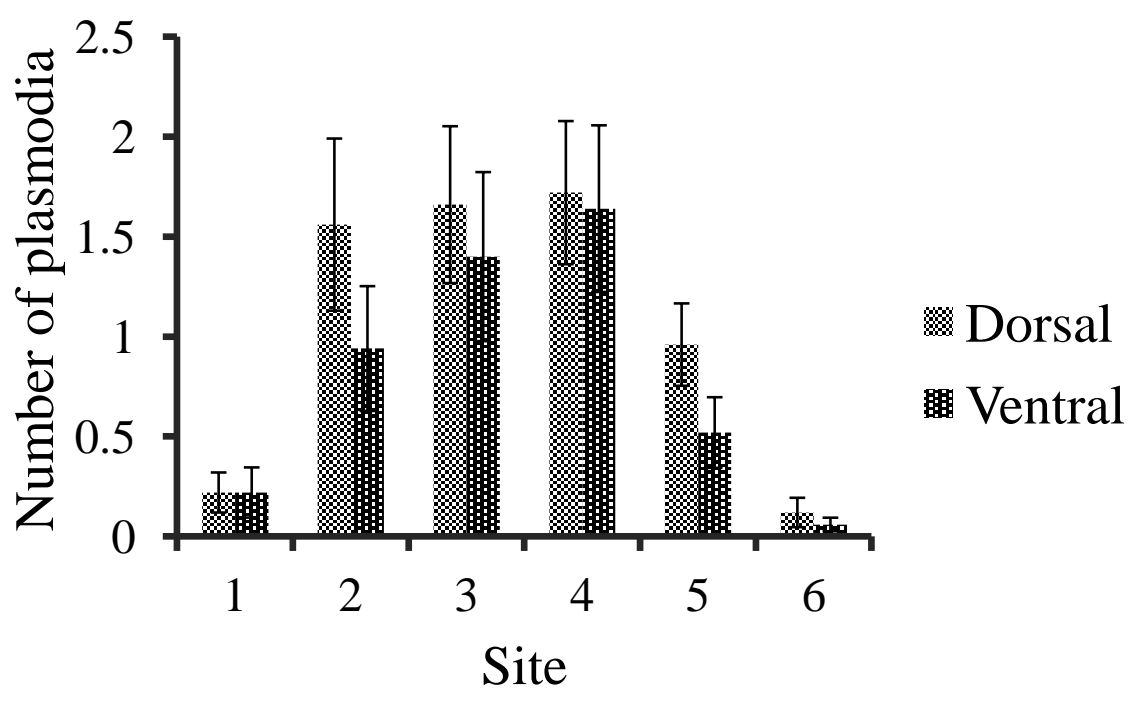

Fig. 2. Distribution of $H$. zschokkei plasmodia within fish, i.e., mean ( \pm s.e.) numbers of plasmodia in different sites of fillet (for positions of the sites, see Fig. 1). Based on $502 \mathrm{y}$ old infected whitefish from fish farm studied in 2009. 


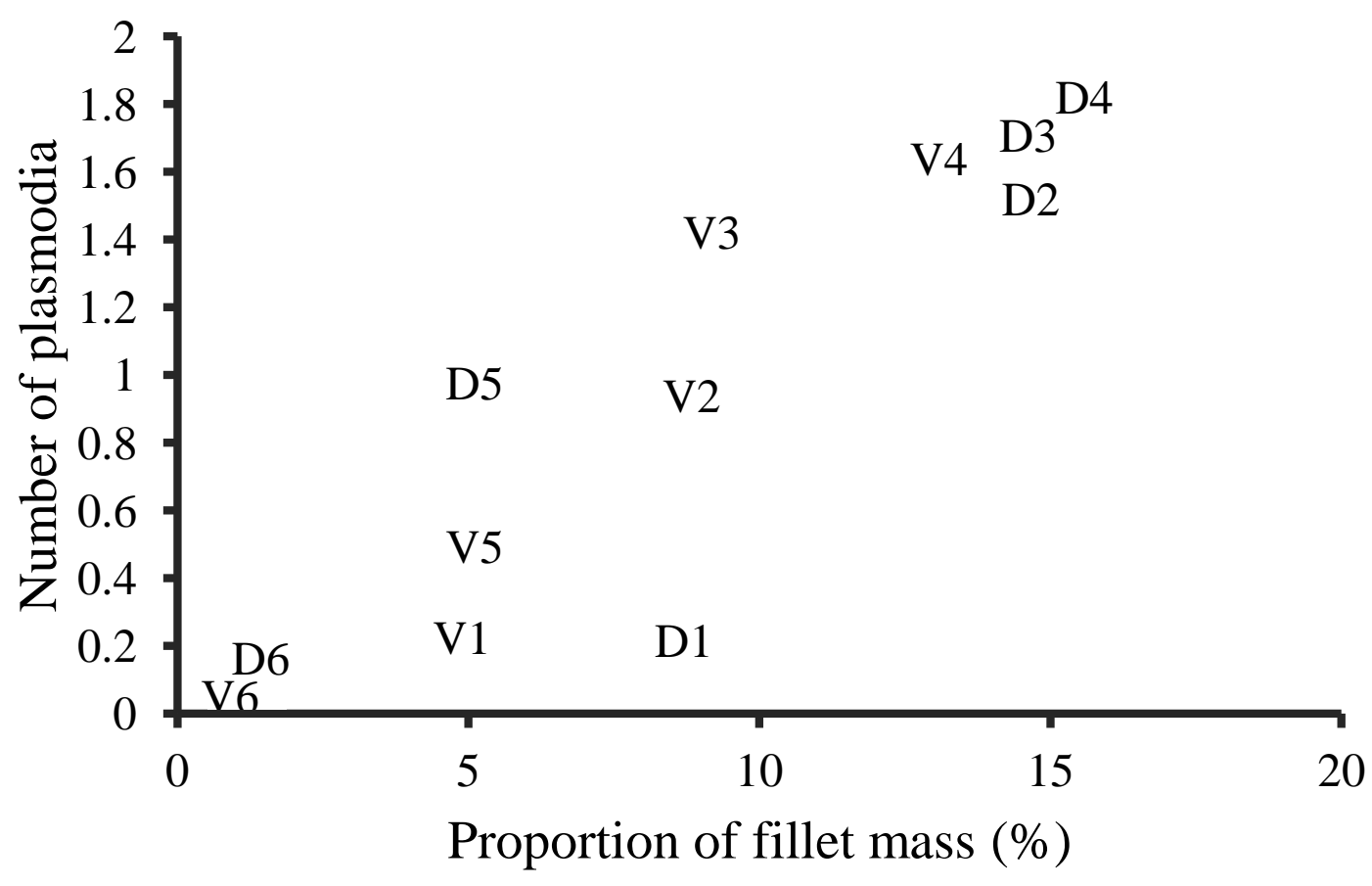

Figure 3. Site specific numbers of $H$. zschokkei plasmodia plotted against site specific muscle masses within fillet (for positions of the sites, see Fig. 1). 


\section{Highlights}

- First study of Henneguya zschokkei (Myxozoa) in cultured whitefish (Coregonus lavaretus)

- Infection prevalence was $0.2 \%$ in $1+, 13.1 \%$ in $2+$ and $17.1 \%$ in $3+y$ fish

- The infection was notable for the first time in August from 1+ and 2+y fish 